\title{
HUBUNGAN FAKTOR PREDISPOSISI DENGAN KEBERADAAN JENTIK NYAMUK AEDES AEGYPTI
}

\author{
RELATIONS OF PREDISPOSING FACTORS WITH LARVA AEDES AEGYPTI \\ EXISTENCE
}

\author{
Riska Wahyuningtias Utami ${ }^{1)}$, Dani Nasirul Haqi ${ }^{2)}$ \\ ${ }^{1,2}$ Departemen Kesehatan dan Keselamatan Kerja Fakultas Kesehatan Masyarakat Universitas \\ Airlangga, Surabaya \\ Email: riska.wahyuningtias.utami-2016@fkm.unair.ac.id
}

\begin{abstract}
The incidence of dengue fever in Indonesia can't be eliminated. There is bumantik program which conducted in Surabaya that expected to decrease dengue fever cases. Several factors that may affect individual behavior are predisposing factors, enabling factors and reinforcing factors. The purposes of study were analyzing relationship of predisposing factors and the presence of Aedes aegypti mosquito larvae. There were two types of variables used in this study they were dependent and independent variables. The independent variables used were gender, age, education, income, knowledge about dengue, attitude towards using abate powder, attitude towards bath drainage action and attitude towards $3 M$ actions while indepent variable used was existence of Aedes aegypti mosquito larvae. The type this research was observasional analytical using cross sectional design and being analyzed with chi square test. This research was conducted in RW VI, Rangkah Village, Tambaksari District, Surabaya City. Sample that used in this study were 211 people, which were obtained through simple random sampling method. Data were collected from observations, questionnaires and in depth interviews. The result showed that p-value of variable $<0.05$. This shows that variables have relationship with the Aedes aegypti mosquito larvae's presence. It can be concluded the variables that have relationship are age, income, knowledge about dengue, attitude towards using abate powder and attitude towards bath drainage.
\end{abstract}

Keywords: dengue fever, predisposing factors, aedes aegypti

Abstrak: Angka kejadian penyakit demam berdarah di Indonesia belum dapat ditiadakan. Terdapat program bumantik yang dilakukan di Kota Surabaya yang diharapkan dapat menurunkan kasus demam berdarah. Beberapa faktor yang dapat mempengaruhi perilaku individu adalah faktor predisposisi, faktor pemungkin dan faktor pendorong. Tujuan dari penelitian ini adalah untuk menganalisis hubungan faktor predisposisi dengan keberadaan jentik nyamuk Aedes aegypti. Jenis variabel yang digunakan pada penelitian ini adalah variabel dependen dan independen. Variabel independen yang digunakan antara lain jenis kelamin, usia, pendidikan, pendapatan, pengetahuan tentang DBD, sikap terhadap penggunaan bubuk abate, sikap terhadap tindakan pengurasan bak mandi dan sikap terhadap tindakan $3 M$ sedangkan variabel indepen yang digunakan adalah keberadan jentik nyamuk Aedes aegypti. Penelitian ini merupakan penelitian observasional analitik dengan pendekatan cross sectional kemudian akan dianalisis menggunakan uji chi-square. Penelitian ini dilakukan di RW VI, Kelurahan Rangkahm Kecamatan Tambaksari, Kota Surabaya. Sampel pada penelitian ini sebesar 211 jiwa dimana didapatkan melalui metode simple random sampling. Data diperoleh dari hasil observasi, kuesioner dan wawancara mendalam. Hasil menunjukkan bahwa nilai p-value variabel <0.05 dimana menunjukkan bahwa variabel tersebut memiliki hubungan dengan keberadaan jentik nyamuk Aedes aegypti. Dapat disimpulkan bahwa variabel yang terdapat hubungan adalah usia, pendapatan, pengetahuan tentang DBD, sikap terhadap penggunaan bubuk abate dan sikap terhadap pengurasan bak mandi.

Kata Kunci: penyakit demam berdarah, faktor predisposisi, aedes aegypti 


\section{PENDAHULUAN}

Hingga saat ini penyakit demam berdarah dengue (DBD) di Indonesia masih menjadi permasalahan kesehatan karena angka penyakit DBD masih belum dapat diturunkan. Beberapa tahun terakhir, jumlah kasus penyakit DBD di Jawa timur mengalami kenaikan. pada tahun 2015 sebanyak 21.092 dan tahun 2016 sebanyak 25.338 kasus (Kementrian Kesehatan Indonesia, 2017).

Berdasarkan Profil Kesehatan

Provinsi Jawa Timur, Terdapat 10 kabupaten/kota dengan kasus DBD tinggi yaitu Kab. Sidoarjo, Kab. Pacitan, Kab. Jember, Kab. Malang, Kab. Trenggalek, Kab.Jombang, Kab. Bondowoso, Kab.Tulungagung, Kab. Kediri dan Kota Surabaya. Kota Surabaya menempati posisi 10 besar kabupaten/kota dengan angka kasus DBD tinggi yaitu sebanyak 938 kasus pada tahun 2016. Namun pada tahun 2017 jumlah kasus DBD mengalami penurunan yaitu menjadi 302 kasus (Dinas Kesehatan Jawa Timur, 2016).

Angka Bebas jentik nyamuk merupakan salah satu indikator suatu wilayah bebas DBD. Sampai dengan tahun 2016 Angka Bebas Jentik (ABJ) tingkat nasional belum mencapai target yaitu sebesar $71,1 \%$ yang seharusnya $\geq 95 \%$ (Profil Kesehatan Indonesia, 2016). Pemberatansan DBD akan lebih efektif jika dilakukan dengan memutus rantainya yaitu melalui Angka Bebas Jentik.

Pada tahun 2015, jumlah pasien DBD di Kota Surabaya sebanyak 640 orang dengan rincian penderita laki-laki 263 orang dan perempuan 377 orang. Sedangkan kasus meninggal pada pasien DBD sebanyak 13 orang, dengan CFR $2,03 \%$ (Dinas Kesehatan, 2015). Terdapat 7 kasus penyakit DBD di wilayah keluurahan Rangkah dimana terdapat 3 kasus pada laki-laki dan 4 kasus pada perempuan (Dinas Kesehatan, 2015).

Angka kasus DBD di Surabaya dapat mengalami penurunan karena Pemerintahan Kota Surabaya menerapkan program pemberantasan sarang nyamuk yaitu program satu rumah satu jumantik dimana setiap rumah diwajibkan memiliki satu orang yang bertanggung jawab mengenai keberadaan jentik di rumah tersebut. Program tersebut dapat berjalan dengan baik karena didukung oleh antusiasme warga yang tinggi didukung oleh sifat peduli terhadap kesehatan tiap individu (Rini, 2012).

Kesehatan individu dipengaruhi faktor yang berasal dari non perilaku dan perilaku. Faktor non perilaku merupakan hal-hal yang dapat mempengaruhi pencapaian kesehatan individu selain dari perilaku masing-masing individu (Notoadmojo, 2007). Beberapa contoh diantaranya adalah kurangnya sarana prasarana fasilitas, sulitnya mencapai sarana pelayanan kesehatan, mahalnya biaya transportasi, mahalnya biaya pengobatan, kebijakan serta peraturan dan lain sebagainya.

Green menjelaskan bahwa perilaku kesehatan dipengaruhi oleh tiga faktor yaitu faktor predisposisi, faktor pemungkin dan faktor penguat (Notoadmojo, 2007). Faktor predisposisi merupakan faktor yang terdapat dalam diri tiap individu yang mampu memotivasi seseorang untuk melakukan sebuah tindakan misalnya usia, pendidikan, status sosial dan ekonomi, sikap dan pengetahuan (Notoadmojo, 2007). Faktor pemungkin merupakan kondisi ketersediaan sarana prasarana yang dapat memotivasi seseorang untuk melakukan sebuah perubahan tindakan contohnya adalah biaya, pelayanan kesehatan dan media informasi. Sedangkan pengertian faktor penguat yaitu faktor yang dapat menguatkan seseorang untuk memperkuat motivasi untuk melakukan perubahan tindakan seperti adanya peraturan, perundangundangan maupun tersedianya kebijakan (Notoadmojo, 2007).

Hasil penelitian terdahulu menunjukkan terdapat hubungan antara tingkat pengetahuan responden, sikap, perilaku responden dengan pelaksanaan pemberantasan sarang nyamuk Aedes aegypti (Rosdiana, 2010 dan Gafur, 2015).

Berdasarkan penelitian sebelumnya, mayoritas faktor predisposisi yang diteliti hanya sebatas usia, pengetahuan dan sikap responden sehingga dalam penelitian ini variabel faktor predisposisi yang diteliti 
hubungannya dengan keberadaan jentik nyamuk Aedes aegypti lebih diperbanyak meliputi jenis kelamin, usia, tingkat pendidikan, tingkat pendapatan, pengetahuan serta sikap responden.

\section{METODE}

Penelitian ini merupakan penelitian observasional analitik dengan pendekatan cross sectional. Populasi dalam penelitian ini adalah warga RW VI Kelurahan Rangkah Kecamatan Tambaksari Kota Surabaya. Penentuan besarnya sampel diperoleh dengan metode Simple Random Sampling. Penentuan banyak sampel ditentukan dengan perhitungan Slovin dan didapatkan besarnya sampel yang digunakan adalah 211 orang.

Pada penelitian ini terdapat variabel independen dan variabel dependen. Variabel independen yang diteliti diantaranya adalah jenis kelamin, usia, pendidikan, pendapatan, pengetahuan tentang DBD, sikap responden terhadap penggunaan bubuk abate, sikap responden terhadap tindakan pengurasan bak mandi dan sikap responden terhadap tindakan $3 \mathrm{M}$.

Sedangkan untuk variabel dependen yang diteliti adalah keberadaan jentik nyamuk Aedes aegypti. Pengumpulan data diperoleh dari data primer berupa hasil wawancara, penyebaran kuesioner dan observasi. Sedangkan data sekunder berupa data demografi warga RW VI Kelurahan Rangkah Kecamatan Tambaksari Kota Surabaya. Hasil penelitian disajikan dalam bentuk deskriptif berupa tabel, distribusi frekuensi serta tabulasi silang.

\section{HASIL DAN PEMBAHASAN}

Berdasarkan gambar 1, dapat diketahui bahwa masih banyak jentik nyamuk di rumah warga dimana terdapat 121 rumah $(57.3 \%)$ yang terdapat jentik dan hanya 90 rumah (42.7\%) yang tidak terdapat jentik nyamuk. Berikut adalah hasil uji chi square faktor predisposisi dengan keberadaan jentik nyamuk Aedes aegypti.

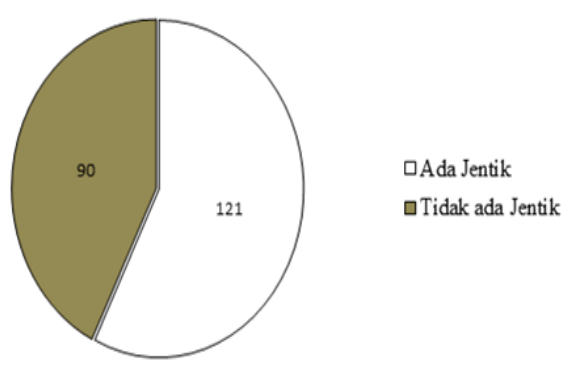

Gambar 1. Distribusi Keberadaan Jentik Nyamuk di RW VI Kelurahan Rangkah Kecamatan Tambaksari Tahun 2018

\section{Jenis Kelamin}

Sex (jenis kelamin) dengan gender hampir selalu dianggap memiliki makna yang sama oleh masyarakat sehingga sering mengakibatkan pemahaman yang salah ataupun pemahaman yang terbalik. Pengertian jenis kelamin adalah atribut fisiologi dan anatomi dimana terdapat perbedaan antara laki-laki dengan perempuan. Sedangkan pengertian gender adalah istilah yang digunakan untuk menunjukan perbedaan antara laki-laki dan perempuan yang di pelajari. Gender merupakan bagian dari sistem sosial, seperti status sosial, usia, dan etnis, itu adalah faktor penting dalam menentukan peran, hak dan kewajiban pada pria serta wanita (Wade dan Tavris, 2007).

Berdasarkan dari tabel 1 menunjukkan bahwa mayoritas penduduk warga RW VI, Kelurahan Rangkah, Kecamatan Tambaksari yang di rumahnya terdapat jentik adalah para responden wanita. Berdasarkan hasil uji chi-square hasil dari $p$-value jenis kelamin adalah 1.000 dimana $>\alpha$ yaitu $5 \%$ maka dapat dikatakan jenis kelamin tidak ada hubungan dengan keberadan jentik nyamuk Aedes aegypti. Sehingga keberadaan jentik nyamuk tidak akan berhubungan dengan jenis kelamin responden. 
Tabel 1. Hasil Uji Chi Square faktor predisposisi yang berhubungan dengan keberadaan jentik nyamuk Aedes aegypti pada Warga RW VI, Kelurahan Rangkah, Kecamatan Tambaksari Tahun 2018

\begin{tabular}{|c|c|c|c|c|c|c|}
\hline \multirow[b]{2}{*}{$\begin{array}{l}\mathbf{N} \\
\mathbf{o .}\end{array}$} & \multirow[b]{2}{*}{ Variabel } & \multicolumn{2}{|c|}{ Keberadaan Jentik } & \multirow[b]{2}{*}{$\begin{array}{l}\text { Total } \\
\text { N (\%) } \\
\end{array}$} & \multicolumn{2}{|c|}{$\begin{array}{c}\text { Hasil Uji Chi } \\
\text { Square }\end{array}$} \\
\hline & & $\begin{array}{c}\text { Ada Jentik } \\
\mathbf{N}(\%) \\
\end{array}$ & $\begin{array}{c}\text { Tidak Ada } \\
\text { Jentik } \\
\text { N (\%) } \\
\end{array}$ & & $\begin{array}{c}\text { p- } \\
\text { value }\end{array}$ & Ket \\
\hline 1. & $\begin{array}{l}\text { Jenis Kelamin } \\
\text { a. Laki-laki } \\
\text { b. } \quad \text { Perempuan }\end{array}$ & $\begin{array}{l}15(57.7 \%) \\
10657.3 \%) \\
\end{array}$ & $\begin{array}{l}11(42.3 \%) \\
79(42.7 \%) \\
\end{array}$ & $\begin{array}{c}26(12.3 \%) \\
185(87.7 \%)\end{array}$ & 1.000 & $\begin{array}{l}\text { Tidak ada } \\
\text { hubungan }\end{array}$ \\
\hline 2. & $\begin{array}{ll}\text { Usia } \\
\text { a. } & \text { Produktif } \\
\text { b. } & \text { Tidak } \\
& \text { produktif } \\
\end{array}$ & $\begin{array}{l}100(54.3 \%) \\
21(77.8 \%)\end{array}$ & $\begin{array}{c}84(45.7 \%) \\
6(22.2 \%)\end{array}$ & $\begin{array}{c}184(87.2 \%) \\
27(12.8 \%)\end{array}$ & 0.023 & $\begin{array}{c}\text { Ada } \\
\text { hubungan }\end{array}$ \\
\hline 3. & $\begin{array}{l}\text { Pendidikan } \\
\text { a. Rendah } \\
\text { b. Menengah } \\
\text { c. Tinggi } \\
\end{array}$ & $\begin{array}{l}42(64.6 \%) \\
18(45.0 \%) \\
61(57.5 \%) \\
\end{array}$ & $\begin{array}{l}23(35.4 \%) \\
22(55.0 \%) \\
45(45.2 \%) \\
\end{array}$ & $\begin{array}{c}65(30.8 \%) \\
40(19.0 \%) \\
106(50.2 \%) \\
\end{array}$ & 0.142 & $\begin{array}{l}\text { Tidak ada } \\
\text { hubungan }\end{array}$ \\
\hline 4. & \begin{tabular}{ll}
\multicolumn{1}{l}{ Pendapatan } \\
a. $<500.000$ \\
b. $500.00-$ \\
1.000 .000 \\
c. $1.1000-$ \\
& 1.500 .000 \\
d. 1 & $1.600 .000-$ \\
& 2.000 .000 \\
e. $>2.100 .000$
\end{tabular} & $\begin{array}{l}21(75.0 \%) \\
13(35.1 \%) \\
22(56.4 \%) \\
24(70.6 \%) \\
41(56.2 \%)\end{array}$ & $\begin{array}{c}7(25.0 \%) \\
24(64.9 \%) \\
17(43.6 \%) \\
10(29.4 \%) \\
32(43.8 \% 0\end{array}$ & $\begin{array}{l}28(13.3 \%) \\
37(17.5 \%) \\
39(18.5 \%) \\
34(16.1 \%) \\
73(34.6 \%)\end{array}$ & 0.009 & $\begin{array}{c}\text { Ada } \\
\text { hubungan }\end{array}$ \\
\hline 5. & $\begin{array}{l}\text { Pengetahuan } \\
\text { DBD } \\
\text { a. Baik } \\
\text { b. Cukup } \\
\text { c. Kurang } \\
\end{array}$ & $\begin{array}{c}73(68.9 \%) \\
9(34.6 \%) \\
39(32.2 \%) \\
\end{array}$ & $\begin{array}{l}33(31.1 \%) \\
17(65.4 \%) \\
40(44.4 \%) \\
\end{array}$ & $\begin{array}{l}108(50.2 \%) \\
28(12.3 \%) \\
79(37.4 \%) \\
\end{array}$ & 0.001 & $\begin{array}{c}\text { Ada } \\
\text { hubungan }\end{array}$ \\
\hline 6. & $\begin{array}{l}\text { Sikap terhadap } \\
\text { penggunaan } \\
\text { bubuk abate } \\
\text { a. SS } \\
\text { b. } \mathrm{S} \\
\text { c. TS } \\
\end{array}$ & $\begin{array}{c}9(100 \%) \\
56(55.4 \%) \\
56(55.4 \%) \\
\end{array}$ & $\begin{array}{c}0(0 \%) \\
45(44.6 \%) \\
45(44.6 \%) \\
\end{array}$ & $\begin{array}{c}9(4.3 \%) \\
101(47.9 \%) \\
101(47.9 \%) \\
\end{array}$ & 0.030 & $\begin{array}{c}\text { Ada } \\
\text { hubungan }\end{array}$ \\
\hline 7. & $\begin{array}{l}\text { Sikap terhadap } \\
\text { tindakan } \\
\text { pengurasan bak } \\
\text { mandi } \\
\text { a. } \mathrm{SS} \\
\text { b. } \mathrm{S} \\
\text { c. } \mathrm{TS}\end{array}$ & $\begin{array}{l}21(77.8 \%) \\
46(43.8 \%) \\
54(68.4 \%) \\
\end{array}$ & $\begin{array}{c}6(22.2 \%) \\
59(56.2 \%) \\
25(31.6 \%) \\
\end{array}$ & $\begin{array}{c}27(12.8 \%) \\
105(49.8 \%) \\
79(37.4 \%) \\
\end{array}$ & 0.000 & $\begin{array}{c}\text { Ada } \\
\text { hubungan }\end{array}$ \\
\hline 8. & $\begin{array}{l}\text { Sikap terhadap } \\
\text { tindakan } 3 \mathrm{M} \\
\text { a. SS } \\
\text { b. S } \\
\text { c. } \mathrm{TS}\end{array}$ & $\begin{array}{l}18(51.4 \%) \\
78(56.1 \%) \\
25(67.6 \%)\end{array}$ & $\begin{array}{l}17(48.6 \%) \\
61(43.9 \%) \\
12(32.4 \%)\end{array}$ & $\begin{array}{c}35(16.6 \%) \\
139(65.9 \%) \\
37(17.5 \%)\end{array}$ & 0.338 & $\begin{array}{l}\text { Tidak ada } \\
\text { hubungan }\end{array}$ \\
\hline
\end{tabular}

Usia

Pengertian usia yang dimaksud dalam penelitian ini adalah jumlah usia responden mulai dari lahir hingga dilaksanakannya penelitian ini. Usia responden dikategorikan menjadi kategori usia produktif dan usia tidak produktif dimana kategori usia produktif adalah 15 tahun-64 tahun sedangkan untuk usia tidak produktif adalah usia $<15$ tahun dan $>65$ tahun. 
Berdasarkan dari tabel 1 menunjukkan bahwa mayoritas penduduk warga RW VI, Kelurahan Rangkah, Kecamatan Tambaksari yang di rumahnya terdapat jentik adalah para responden dengan kategori usia produktif. Hasil dari $p$-value usia adalah 0.023 dimana $<\alpha$ yaitu 5\% sehingga disimpulkan bahwa ada hubungan dengan keberadan jentik nyamuk Aedes aegypti. Terdapatnya hubungan antara usia dengan keberadaan jentik nyamuk Aedes aegypti dapat diartikan apabila responden termasuk dalam kategori usia produktif maka seharusnya tidak ditemukannya jentik nyamuk Aedes aegypti pada area tempat tinggal responden tersebut.

Hal tersebut karena apabila seseorang berada pada usia produktif maka akan cenderung untuk lebih sadar dan paham mengenai kebersihan dan kesehatan karena masih mampu untuk melakukan banyak kegiatan seperti membersihkan rumah dan lingkungan sekitar.

Namun realitanya tidak demikian, hasil yang didapatkan pada warga kelurahan Rangkah yang termasuk pada usia produktif setelah dilakukan pemeriksaan keberadaan jentik nyamuk di rumah masing-masing mendapatkan hasil yaitu mayoritas terdapat jentik nyamuk Aedes aegypti baik pada bak mandi maupun beberapa tempat penyimpanan air.

Salah satu hal yang dapat mempengaruhi adalah sebagian besar warga RW VI Kelurahan Rangkah Kecamatan Tambaksari memiliki pekerjaan sebagai wiraswasta. Mayoritas baik suami maupun istri memiliki pekerjaan sehingga kedua belah pihak tidak memiliki banyak waktu luang dan sibuk dengan pekerjaan masing-masing sehingga terkadang terlupa untuk menguras bak mandi di rumah masingmasing.

Warga biasanya hanya mengisi kembali bak penampungan air di kamar mandi apabila sudah tinggal sedikit tanpa mengurasnya terlebih dahulu. Apabila sudah memiliki waktu luang, baru warga akan mengurasnya dan melakukan penyikatan pada bak penampungan di kamar mandi mereka masing-masing. Hal tersebut dapat menyebabkan keberadaan jentik nyamuk Aedes aegypti di bak mandi menjadi semakin banyak karena jarang dikuras.

\section{Pendidikan}

Definisi pendidikan adalah upaya manusia untuk memperbaiki dan meningkatkan keahlian yang dimiliki baik keahlian fisik maupun mental agar dapat diterima di masyarakat (Fuad, 2007). Tingkat pendidikan responden dikategorikan menjadi 3 kategori yaitu pendidikan rendah, menengah dan tinggi. Kategori pendidikan rendah yaitu apabila responden berpendidikan terakhir Sekolah Dasar (SD) atau tidak bersekolah sedangkan untuk kategori pendidikan menengah yaitu apabila responden berpendidikan Sekolah Menengah Pertama (SMP) dan kategori pendidikan tinggi apabila responden berpendidikan Sekolah Menengah Atas (SMA) maupun Sarjana (D3/S1).

Berdasarkan dari tabel 1 menunjukkan bahwa mayoritas penduduk warga RW VI, Kelurahan Rangkah, Kecamatan Tambaksari yang di rumahnya terdapat jentik justru para responden dengan tingkat pendidikan yang tinggi. Namun untuk jumlah rumah yang tidak terdapat jentik juga didominasi oleh responden dengan pendidikan tinggi.

Hasil dari $p$-value pendidikan adalah 0.142 dimana $>\alpha$ yaitu $5 \%$ maka dapat dikatakan pendidikan tidak ada hubungan dengan keberadan jentik nyamuk Aedes aegypti. Berdasarkan teori menyatakan bahwa tingkat pendidikan seseorang akan mempengaruhi respon yang akan dilakukan oleh masing-masing individu. Individu yang memiliki pendidikan tinggi dapat memberi respon yang lebih rasional serta berpikir tentang keuntungan serta kerugiaan dari informasi tersebut.

Namun hasil yang didapatkan justru sebaliknya dimana responden dengan pendidikan tinggi masih terdapat jentik nyamuk Aedes aegypti di rumahnya. Beberapa faktor yang dapat mempengaruhi hal tersebut adalah kurangnya media informasi yang benar terkait masalah DBD terutama cara 
pemberantasan jentik nyamuk Aedes aegypti.

\section{Pendapatan}

Pendapatan secara umum dapat diartikan sebagai banyaknya jumlah penerimaan yang dinilai dengan suatu mata uang tertentu yang dihasilkan oleh seseorang setelah melakukan sebuah usaha. Berdasarkan dari tabel 1 menunjukkan bahwa mayoritas penduduk warga RW VI, Kelurahan Rangkah, Kecamatan Tambaksari yang di rumahnya terdapat jentik justru para responden dengan tingkat pendapatan tertinggi yaitu diatas >2.100.000. Namun untuk jumlah rumah yang tidak terdapat jentik juga didominasi oleh responden dengan pendapatan tinggi yaitu diatas $>2.100 .000$.

Hasil dari $p$-value pendapatan adalah 0.009 dimana $<\alpha$ yaitu $5 \%$ sehingga disimpulkan bahwa ada hubungan antara tingkat pendapatan dengan keberadan jentik nyamuk Aedes aegypti. Terdapatnya hubungan antara pendapatan dengan keberadaan jentik nyamuk Aedes aegypti dapat diartikan apabila semakin besar tingkat pendapatan maka seharusnya tidak ditemukannya jentik nyamuk Aedes aegypti pada area tempat tinggal responden tersebut.

Hal tersebut dikarenakan apabila sebuah keluarga memiliki pendapatan tinggi maka kebutuhan primer dan kebutuhan sekunder dapat mudah tercukupi dibandingkan keluarga yang memiliki pendapatan rendah. Sehingga tingkat pendapatan dapat mempengaruhi pemenuhan kebutuhan baik kebutuhan primer maupun kebutuhan sekunder diantaranya kebutuhan akan informasi pengetahuan yang termasuk kebutuhan sekunder.

Namun pada penelitian ini yang terjadi justru sebaliknya dimana responden dengan pendapatan tinggi masih terdapat jentik nyamuk Aedes aegypti di rumahnya. Beberapa faktor yang dapat mempengaruhi hal tersebut adalah kurangnya informasi terkait masalah DBD terutama cara pemberantasan jentik nyamuk Aedes aegypti dan terdapat kemungkinan pemberantasan jentik nyamuk Aedes aegypti bukan menjadi prioritas utama dalam rencana pengeluaran keluarga mereka. Sebagian besar pendapatan yang didapatkan responden diprioritaskan untuk digunakan dalam memenuhi kebutuhan hidup juga digunakan untuk modal usaha maupun untuk merenovasi tempat tinggal.

\section{Pengetahuan}

Pembagian jenis pengetahuan berdasarkan sifat pengetahuan yaitu dibedakan menjadi pengetahuan langsung dan pengetahuan tidak langsung dimana pengetahuan langsung merupakan pengetahuan yang didapatkan tanpa pemahaman mendalam terlebih dahulu misalnya seperti informasi yang dapat diperoleh dari lingkungan sekitar. Pengetahuan tidak langsung dapat diperoleh dari hal-hal yang pernah dilakukan terdahulu atau berasal dari pengalaman individu.

Notoatmodjo (2007) menyatakan bahwa pengetahuan adalah salah satu hal yang berpengaruh dalam terbentuknya perilaku masing-masing individu (overt behavior). Perilaku yang disertai dengan kepemilikan pengetahuan yang mumpuni dapat bertahan lama apabila tanpa dilengkapi dengan kepemilikian pengetahuan yang mumpuni. Terdapat beberapa proses sebelum seseorang mengadopsi sebuah perilaku baru yaitu: awareness, interest, evaluation, trial dan adoption.

Berdasarkan dari tabel 1 menunjukkan bahwa mayoritas penduduk warga RW VI, Kelurahan Rangkah, Kecamatan Tambaksari yang di rumahnya terdapat jentik justru para responden dengan pengetahuan tentang DBD yang baik. Berdasarkan hasil uji chi-square hasil dari $p$-value pengetahuan tentang DBD adalah 0.001 dimana $<\alpha$ yaitu $5 \%$ sehingga disimpulkan bahwa ada hubungan antara tingkat pengetahuan dengan keberadan jentik nyamuk Aedes aegypti.

Terdapatnya hubungan antara tingkat pengetahuan tentang DBD dengan keberadaan jentik nyamuk Aedes aegypti dapat diartikan apabila semakin baik tingkat pengetahuan tentang DBD maka seharusnya tidak ditemukannya jentik 
nyamuk Aedes aegypti pada area tempat tinggal responden tersebut. Hal tersebut dikarenakan apabila responden memiliki tingkat pengetahuan tentang DBD yang baik maka responden tersebut dapat dikatakan telah mengetahui, memahami dan mampu untuk melakukan beberapa cara untuk mencegah munculnya jentik nyamuk Aedes aegypti di area tempat tinggalnya.

Namun pada penelitian ini yang terjadi justru sebaliknya dimana responden dengan pengetahuan tentang DBD dengan kategori baik masih terdapat keberadaan jentik nyamuk Aedes aegypti di rumahnya. Beberapa faktor yang dapat mempengaruhi hal tersebut adalah akibat kondisi individu yang masih berada pada tahapan awareness dimana individu sudah memiliki kesadaran dalam dirinya mengenai pencegahan penyakit DBD namun belum dapat menerima ataupun belum terbiasa dengan tindakan baru yaitu tindakan untuk menguras bak mandi secara teratur minimal seminggu sekali.

Hal tersebut dapat diantisipasi dengan cara memberikan pendidikan kesehatan kepada masyarakat. Kegiatannya dapat berupa sosialisasi tentang kesehatan sehingga dapat memberikan informasi serta mengajak masyarakat untuk memiliki keinginan hidup lebih sehat serta dapat menjalankan pola hidup sehat. Pemberian informasi mengenai kesehatan dapat lebih bermanfaat jika dipaparkan ketika belum terdapat korban yang terjangkit penyakit DBD. Hal-hal yang dapat dilakukan adalah melakukan sosialisasi tentang mencegah penyakit demam berdarah, gejala-gejala penyakit demam berdarah serta langkah awal untuk mengatasi apabila salah satu anggota keluarga menunjukkan salah satu gejala terjangkit penyakit demam berdarah. Informasi baru tersebut dapat meningkatkan pengetahuan individu serta meningkatkan kewaspadaan masyarakat terhadap penyakit demam berdarah.

\section{Sikap Terhadap Penggunaan Bubuk Abate}

Terdapat beberapa metode pengendalian vektor yaitu pengendalian lingkungan, pengendalian biologi dan pengendalian kimia (Kemenkes RI, 2011; WHO, 2011). Pengendalian lingkungan dapat dilakukan dengan cara memanipulasi atau membuat kondisi lingkungan menjadi tidak sesuai dengan kondisi lingkungan yang dibutuhkan vektor untuk berkembang biak dan dengan cara mengurangi kontak langsung antara vektor dengan manusia.

Pencegahan penyakit demam berdarah dapat diawali dengan cara memutus siklus kehidupan nyamuk penyebab demam berdarah. Salah satu fase yang dapat diputus adalah ketika fase larva karena pada fase telur waktu yang dibutuhkan untuk menjadi larva sangat cepat dan telur nyamuk terlalu kecil ukurannya sehingga sulit untuk dilihat secara kasat mata.

Pemberantasan larva nyamuk penyebab demam berdarah dapat dilakukan dengan cara memanfaatkan ikan dan bakteri. Ikan yang dapat dimanfaatkan adalah ikan Lavivorus sedangkan untuk bakteri yang dapat digunakan adalah bakteri Bacillus thuringiensis serotype $\mathrm{H}-14$ (Bt.H-14) dan Bacilus sphaericus (B). Sedangkan pengendalian secara kimia dapat dilakukan dengan cara penggunaan larvasida (bubuk abate) dan fogging. Namun untuk pengendalian secara kimia dapat menimbulkan dampak negatif terhadap lingkungan.

Berdasarkan dari tabel 1 menunjukkan bahwa beberapa penduduk warga RW VI, Kelurahan Rangkah, Kecamatan Tambaksari memiliki sikap setuju terhadap penggunaan bubuk abate untuk memberantas jentik nyamuk Aedes aegypti sedangkan sebagian lainnya memiliki sikap tidak setuju terhadap penggunaan bubuk abate untuk memberantas jentik nyamuk Aedes aegypti.

Tidak terdapat keberadaan jentik di rumah penduduk yang memiliki sikap cenderung setuju dalam penggunaan abate sedangkan pada rumah penduduk yang memiliki sikap tidak setuju masih ditemukan keberadaan jentik nyamuk Aedes aegypti di rumahnya. Berdasarkan hasil uji chi-square hasil dari p-value sikap terhadap penggunaan bubuk abate adalah 0.030 dimana $<\alpha$ yaitu $5 \%$ 
sehingga dapat dikatakan bahwa ada hubungan antara sikap terhadap penggunaan bubuk abate dengan keberadan jentik nyamuk Aedes aegypt

Adanya hubungan antara sikap responden terhadap penggunaan bubuk abate dengan keberadaan jentik nyamuk Aedes aegypti dapat diartikan semakin setuju terhadap penggunaan bubuk abate maka seharusnya tidak ditemukannya jentik nyamuk Aedes aegypti pada area tempat tinggal responden tersebut.

Hal tersebut dikarenakan apabila seseorang merasa setuju terhadap sebuah tindakan seharusnya responden tersebut akan menerapkannya dalam bentuk nyata yaitu sebuah perilaku. Contoh dalam penelitian ini adalah apabila responden setuju dengan penggunaan abate untuk memberantas jentik nyamuk Aedes aegypti maka seharusnya responden tersebut juga melakukan penebaran bubuk abate pada tempat penampungan air yang terdapat di rumah dan lingkungan sekitarnya.

Namun berdasarkan hasil penelitian didapatkan hasil bahwa sebagian penduduk memiliki sikap setuju dan sisanya memiliki sikap tidak setuju terhadap penggunaan bubuk abate. Namun pada warga yang memiliki sikap setuju tingkat keberadaan jentik lebih rendah dibandingkan dengan tingkat keberadaan jentik pada rumah warga yang memiliki sikap tidak setuju.

Berdasarkan hasil indepth interview menjelaskan beberapa faktor yang dapat mempengaruhi hal tersebut adalah penyebaran pembagian bubuk abate yang tidak merata pada masingmasing wilayah sehingga pada wilayah yang tidak mendapat bubuk abate sehingga tingkat keberadaan jentik masih tinggi dan memiliki sikap tidak setuju karena mereka tidak pernah mendapat bubuk abate atau mereka mendapatkan bubuk abate namun tidak rutin seperti wilayah lainnya.

Selain itu, beberapa warga menyatakan bahwa mereka pernah dittawari untuk membeli bubuk abate dari oknum tertentu yang tidak dapat dipastikan apakah bubuk abate tersebut asli atau tidak.

\section{Sikap Terhadap Tindakan Menguras Bak Mandi Perlu Dilakukan Secara Teratur, Minimal 1 Minggu Sekali}

Penjelasan sikap berdasarkan Sarnoff dalam tulisan Sarwono (2000) adalah respon terhadap sebuah stimulan tertentu dimana individu dapat memberikan respon secara positif maupun memberikan respon secara negatif. Sikap yang dipilih oleh individu tersebut selain dipengaruhi oleh stimulan juga dapat dipengaruhi oleh hal-hal lain diantaranya adalah kejadian yang pernah dialami oleh individu tersebut, budaya, orang yang berpengaruh serta peran media massa.

Menguras merupakan tindakan membuang maupun mengosongkan air yang ada di dalam bak mandi dengan tujuan untuk mencegah nyamuk Aedes aegypti untuk berkembang biak. Nyamuk Aedes aegypti meletakkan telurnya pada air yang jernih misalnya pada bak mandi. Oleh karena itu bak mandi harus sering dikuras untuk mencegah telur nyamuk untuk berkembang biak.

Berdasarkan dari Tabel 1 menunjukkan bahwa mayoritas penduduk warga RW VI, Kelurahan Rangkah, Kecamatan Tambaksari yang di rumahnya terdapat jentik justru para responden yang setuju dengan adanya tindakan menguras bak mandi secara teratur minimal seminggu sekali.

Berdasarkan hasil uji chi-square, p-value sikap terhadap tindakan pengurasan bak mandi secara teratur minimal seminggu sekali adalah 0.000 dimana $<0.05$ sehingga disimpulkan bahwa ada hubungan dengan keberadaan jentik nyamuk Aedes aegypti.

Adanya hubungan antara sikap responden terhadap tindakan pengurasan bak mandi dengan keberadaan jentik nyamuk Aedes aegypti dapat diartikan semakin setuju terhadap tindakan pengurasan bak mandi maka seharusnya tidak ditemukannya jentik nyamuk Aedes aegypti pada area tempat tinggal responden tersebut.

Hal tersebut dikarenakan apabila seseorang merasa setuju terhadap sebuah tindakan seharusnya responden tersebut akan menerapkannya dalam bentuk nyata yaitu sebuah perilaku. Contoh dalam penelitian ini adalah apabila responden 
setuju dengan pengurasan bak mandi minimal $1 \mathrm{x}$ dalam seminggu maka seharusnya responden tersebut juga melakukan pengurasan bak mandi minimal $1 \mathrm{x}$ dalam seminggu secara rutin.

Namun, hasil yang didapatkan tidak demikian dimana responden dengan sikap setuju dan sangat setuju terhadap tindakan pengurasan bak mandi secara teratur minimal seminggu sekali masih ditemukan terdapat keberadaan jentik nyamuk Aedes aegypti di rumahnya.

Salah satu hal yang dapat mempengaruhi adalah pengalaman pribadi, dimana responden sudah memiliki sikap setuju namun dalam pelaksanaannya masih kurang baik dikarenakan mereka belum mengalami sendiri apabila terdapat salah satu anggota keluarga mereka yang terjangkit penyakit DBD. Hal ini terbukti dengan responden yang salah satu anggotanya pernah terjangkit penyakit DBD maka akan lebih bersikap lebih aktif lagi dalam memberantas jentik nyamuk Aedes aegypti. Hal tersebut dikarenakan pengalaman pribadi tersebut akan menciptakan ingatan yang melekat dan mendalam sehingga sikap akan lebih mudah terbentuk.

Faktor selanjutnya adalah kebudayaan dimana lingkungan (kebudayaan) dapat mempengaruhi kepribadian seseorang. Apabila di wilayah tersebut warga sudah terbiasa melakukan pengurasan bak mandi maka tindakan tersebut akan dengan sendirinya menjadi sebuah kebudayaan. Faktor ketiga adalah individu yang memiliki pengaruh terhadap individu lainnya sehingga apabila individu tersebut melakukan tindakan tertentu maka individu lainnya akan mengikuti tindakan yang dilakukan oleh individu berpengaruh tersebut.

Faktor terakhir adalah media massa dimana sebagai salah satu sarana pembentukan pola pikir beserta rasa percaya masyarakat. Apabila terdapat informasi yang belum pernah disampaikan maupun belum pernah dibahas sebelumnya kemudian informasi tersebut disampaikan melalui media massa maka dapat mempengaruhi terbentuknya arah sikap masyarakat terhadap informasi tersebut.
Faktor lain yang dapat mempengaruhi adalah kondisi sumber air yang warga gunakan memang sudah terdapat jentik nyamuk di dalamnya. Misalnya apabila warga menggunakan sumur sebagai sumber air namun keadaan sumur tersebut mengandung banyak jentik nyamuk Aedes aegypti maka walaupun dilakukan tindakan pengurasan bak penampungan air di kamar mandi secara teratur maka tidak akan berpengaruh dengan keberadaan jentik nyamuk Aedes aegypti.

\section{Sikap Terhadap Tindakan 3M}

Berdasarkan dari Tabel 1 menunjukkan bahwa beberapa penduduk warga RW VI, Kelurahan Rangkah, Kecamatan Tambaksari memiliki sikap setuju terhadap tindakan $3 \mathrm{M}$ untuk memberantas keberadaan jentik nyamuk Aedes aegypti. Hasil dari p-value sikap terhadap tindakan $3 \mathrm{M}$ adalah 0.338 dimana $>\alpha$ yaitu $5 \%$ sehingga disimpulkan bahwa tidak ada hubungan antara sikap terhadap tindakan 3M dengan keberadan jentik nyamuk Aedes aegypti.

Hasil yang didapatkan yaitu responden yang memiliki sikap setuju terhadap tindakan $3 \mathrm{M}$ justru tingkat keberadaan jentik nyamuk Aedes aegypti di rumahnya paling tinggi. Beberapa faktor yang dapat mempengaruhi hal tersebut adalah dimana kesadaran untuk melakukan gerakan $3 \mathrm{M}$ baru muncul sehingga warga masih mencoba merubah perilaku mereka menjadi lebih baik dalam melakukan 3M. Hal tersebut sejalan dengan hasil indepth interview dimana warga menyatakan bahwa kegiatan pemberantasan sarang nyamuk (PSN) di wilayah mereka sempat vakum dan baru akan aktif kembali.

Pencegahan penyakit demam berdarah dapat dimulai dengan cara memusnahkan sarang nyamuk penyebab demam berdarah dimana salah satu cara yang dapat dilakukan adalah dengan tindakan 3M. Tindakan 3M merupakan langkah-langkah untuk memastikan bahwa tidak terdapat jentik nyamuk di dalam rumah maupun di lingkungan sekitar rumah.

Tindakan 3M terdiri atas menutup tempat-tempat yang dapat digenangi oleh 
air bersih seperti tempat penampungan air, menguras tempat-tempat yang dapat diisi oleh air misalnya seperti bak mandi dan mengubur barang-barang yang tidak terpakai lagi namun dapat digenangi air misalnya seperti kaleng bekas.

Tindakan 3M adalah tindakan yang banyak disosialisasikan kepada masyarakat karena dianggap cara paling aman, mudah, cepat dan dapat dilakukan oleh semua kalangan dengan sedikit tambahan wawasan dan penjelasan panduan melakukan tindakan 3M. Setiap anggota keluarga dapat melakukannya bahkan anak-anak sekalipun. Gerakan 3M turut melibatkan anak usia sekolah dalam pelaksanaannya sehingga dapat dimanfaatkan dalam suatu upaya pemberdayaan masyarakat untuk lebih peduli demam berdarah.

Masyarakat masih terpaku pada cara pemberantasan penyakit demam berdarah dengan pengasapan (fogging). Perlu diketahui bahwa pengasapan atau fogging hanya dapat membunuh nyamuk dewasa dan hanya pada luasan area tertentu saja. Hal tersebut tidak dapat memastikan siklus hidup nyamuk Aedes aegypti akan terputus.

Fogging mampu membunuh 1 nyamuk dewasa namun tidak bisa membunuh 200 telur nyamuk. Oleh karena itu lebih dianjurkan untuk melakukan 3M untuk mencegah sekaligus memberantas perkembangbiakan nyamuk Aedes aegypti.

Masyarakat lebih senang untuk mengandalkan tindakan fogging ketika terdapat kasus demam berdarah. Hal itu dapat disebabkan karena kurangnya pemahaman masyarakat terhadap perbedaan kebutuhan antara fogging dan gerakan 3M. Keduanya memiliki tingkat prioritas yang berbeda dimana fogging dilakukan berdasarkan kebutuhan yang memenuhi beberapa syarat yakni 1) terdapatnya pasien demam berdarah yang meninggal di satu kawasan; 2) lebih dari dua orang terjangkit demam berdarah; 3 ) lebih dari tiga orang mengalami demam tanpa sebab; 4) hingga terdapatnya jentik nyamuk Aedes aegypti di kawasan tersebut.

Fogging harus dilakukan secara bersamaan untuk membasmi nyamuk dewasa secara keseluruhan. Hal itu terkait kemungkinan berpindahnya nyamuk jika fogging hanya dilakukan dalam satu kawasan saja. Oleh karena itu hal utama yang sangat penting untuk mencegah demam berdarah adalah pola hidup bersih masing-masing individu serta menjaga kebersihan lingkungan sekitar

Masyarakat dapat melakukan kegiatan sederhana diantaranya dengan memastikan kebersihan lingkungan rumah yang rentan menjadi lokasi berkembangbiaknya nyamuk Aedes aegypti. Masyarakat perlu lebih aware tentang kebersihan lingkungan hidup mereka. Karena tidak bisa sekedar mengandalkan tindakan petugas kesehatan, masyarakat juga harus aktif berperan

\section{Pandangan Ketidakkonsistenan Antara Faktor Predisposisi dengan Tindakan Responden Berdasarkan Teori Disonansi Kognitif}

Teori disonansi kognitif milik Leon Festinger merupakan sebuah teori yang membahas ketidakkonsistenan sebuah sikap tertentu sehingga menimbulkan kebingungan dalam mengambil keputusan (Hutagalung, 2016).

Terdapat 3 jenis hubungan yang akan terbentuk akibat disonansi kognitif yaitu hubungan konsonan, hubungan tidak berhubungan dan hubungan tidak selaras (disonan) (Hutagalung, 2016).

Hubungan konsonan merupakan hubungan yang akan terjadi apabila terdapat 2 kognitif dan sikap responden yang saling konsisten. Hubungan tidak berhubungan akan terjadi apabila terdapat 2 kognitif dan sikap yang saling tidak berhubungan dengan satu sama lain. Sedangkan untuk hubungan tidak selaras adalah hubungan yang terjadi ketika 2 kognitif dan sikap yang saling tidak selaras antara satu sama lain (Hutagalung, 2016).

Pada hasil penelitian ini apabila dibahas menggunakan teori disonansi kognitif hubungan yang terjadi adalah hubungan tidak selaras dimana responden dengan usia produktif, memiliki tingkat pendapatan besar, memiliki tingkat pengetahuan tentang DBD baik, setuju terhadap penggunaan bubuk abate dan setuju terhadap tindakan pengurasan bak 
mandi minimal 1x seminggu justru masih terdapat jentik nyamuk Aedes aegypti di sekitar lingkungan tempat tinggalnya.

Faktor yang dapat menyebabkan hal-hal tersebut terjadi adalah adanya ketidakkonsistenan antara usia, pendapatan, pengetahuan dan sikap responden dalam menentukan tindakan mereka. Ketidakkonsistenan tersebut terjadi akibat beberapa hal diantaranya pengalaman dan kepercayaan.

Pada aspek pengalaman, mayoritas warga yang telah memiliki pengalaman terjangkit penyakit DBD akan lebih waspada dan peduli terhadap pencegahan penyakit DBD karena sudah pernah mengalami secara langsung maupun salah satu keluarga yang mengalami. Sedangkan warga yang belum pernah terjangkit DBD maka akan mengesampingkan tindakan pencegahan DBD karena mereka merasa tidak akan terjangkit DBD walaupun tidak melakukan tindakan pencegahan penyakit DBD.

Aspek kepercayaan yang dimaksud adalah kepercayaan warga terhadap keefektifan fogging dalam memberantas penyakit DBD. Warga mempercayai bahwa apabila sudah dilakukan upaya fogging maka sudah cukup dan wilayah mereka tidak akan terjangkit penyakit DBD sehingga sedikit mengesampingkan bahkan tidak memperdulikan tindakan pencegahan DBD lainnya. Terdapat beberapa cara untuk menurunkan ketidakkonsistenan faktor-faktor tersebut diantaranya adalah merubah kepercayaan, merubah tindakan dan mengubah persepsi.

\section{SIMPULAN}

Berdasarkan hasil uji chi square faktor predisposisi masyarakat yang berhubungan dengan keberadaan jentik nyamuk Aedes aegypti di wilayah RW VI, Kelurahan Rangkah, Kecamatan Tambaksari, Kota Surabaya adalah usia, pendapatan, pengetahuan tentang DBD, sikap terhadap tindakan penggunaan bubuk abate dan sikap terhadap tindakan pengurasan bak mandi.

Responden dengan usia produktif, memiliki tingkat pendapatan besar, memiliki tingkat pengetahuan tentang DBD baik, setuju terhadap penggunaan bubuk abate dan setuju terhadap tindakan pengurasan bak mandi minimal $1 \mathrm{x}$ seminggu maka seharusnya tidak ditemukan jentik nyamuk Aedes aegypti pada area tempat tinggal responden namun dalam penelitian ini hasil yang didapatkan adalah sebaliknya.

Hal tersebut terjadi akibat terjadinya hubungan tidak selaras dimana menurut teori disonansi kognitif disebabkan oleh ketidakkonsistenan tindakan akibat tidak selarasnya antara kognitif dan sikap responden.

\section{DAFTAR PUSTAKA}

Carole Wade dan Carol Tavris. 2007 Psikologi. alih bahasa Widyasinta. Jakarta: Erlangga.

Festinger, L. (1957). A Theory of Cognitive Dissonance. Evanston, IL: Row $\&$ Peterson.

Gafur, Abd. 2015. Faktor yang Berhubungan dengan Keberadaan jentik Nyamuk Aedes aegypti di Kelurahan Batua Kota Makassar Tahun 2015. Public Health Science Journal.

Hutagalung, I. 2016. Disonansi Kognitif pada Perilaku Seks Pranikah. Jurnal Komunikasi Ikatan Sarjana Komunikasi Indonesia, Vol. 01 No. 02.

Kementerian Kesehatan RI. 2017. Profil Kesehatan Indonesia. Jakarta : Kementrian Kesehatan Republik Indonesia.

Kementerian Kesehatan RI. 2017. Profil Kesehatan Provinsi Jawa Timur. Surabaya : Dinas Kesehatan Provinsi Jawa Timur.

Notoatmodjo, S. 2007. Promosi Kesehatan dan Ilmu Perilaku. Jakarta: Rineka Cipta.

Rini, dkk. 2012. Hubungan Pemberdayaan Ibu Pemantau Jentik (Bumantik) dengan Indikator Keberhasilan Pemberantasan Sarang Nyamuk (PSN) di Kelurahan 
Wonokromo Surabaya. Dikutip dari: journal.unair.ac.id/download-fullpapersArta\%20S.docx

Rosdiana. 2010. Hubungan Tingkat Pengetahuan, Sikap, Dan Perilaku Dengan Pelaksanaan Pemberantasan Sarang Nyamuk Demam Berdarah
Dengue Di RT. 02 Desa Loa Janan Ulu Wilayah Kerja Puskesmas Loa Janan Kabupaten Kutai Kertanegara, Provinsi Kalimantan Timur.

Sarwono. 2000. Teori-Teori Psikologi Sosial. Jakarta: Raja Grafindo Persada. 